\title{
Edukacja na rzecz zrównoważonego rozwoju - refleksje przed ogłoszeniem nowej Dekady na rzecz Zrównoważonego Rozwoju (2020-2030)
}

\author{
Education for Sustainable Development - Reflections Before the Announcement \\ of the New Decade for Sustainable Development (2020-2030)
}

\author{
Anna Batorczak ${ }^{1}$, Agnieszka Klimska ${ }^{2^{*}}$ \\ ${ }^{1}$ Uniwersyteckie Centrum Badań nad Środowiskiem Przyrodniczym i Zrównoważonym Rozwojem, Uniwersytet Warszawski \\ ${ }^{2}$ Uniwersytet Kardynała Stefana Wyszyńskiego w Warszawie \\ ORCID: AB https://www.orcid.org/0000-0001-7740-3586; AK https://www.orcid.org/0000-0002-9115-9492 \\ *a.klimska@uksw.edu.pl \\ Zgłoszono: 9.03.2020; zrecenzowano: 4.04.2020; zaakceptowano do druku: 6.04.2020
}

\begin{abstract}
Streszczenie: Artykuł prezentuje analizę stanu edukacji na rzecz zrównoważonego rozwoju (EZR) w Polsce przed ogłoszeniem Dekady na rzecz Zrównoważonego Rozwoju 2020-2030. Jego celem była ocena realizacji EZR w naszym kraju oraz wypracowanie zaleceń w zakresie jej uskuteczniania. Dokonano analizy aktualnych podstaw programowych dla szkoły podstawowej, liceum i technikum, a następnie ukazano korzyści wynikające z prowadzenia EZR. Odniesiono się do badań przeprowadzonych w tym zakresie przez ekspertów z Uniwersytetu Stanforda oraz projektu „Badacz Wody”. Wyniki pokazują, że choć w podstawie programowej uwzględniono koncepcję zrównoważonego rozwoju, to w praktyce nadal realizowane są treści edukacji ekologicznej. Okazuje się, że wobec wszystkich korzyści oraz oczekiwań EZR nie stanowi serca i siły napędowej całego systemu edukacyjnego w Polsce. Potrzeba programów umożliwiających nabywanie umiejętności i kompetencji służących ochronie środowiska oraz działań motywujących do odpowiedzialnego reagowania na zmiany, jakie się w nim dokonują. EZR powinna być włączana do polityk i strategii, rozwijana w programach nauczania i powszechnie realizowana w szkołach. Należy też przygotowywać nauczycieli do prowadzenia EZR, wskazywać na efektywne metody i wyposażać w odpowiednie narzędzia jej wdrażania. Pozostaje nadzieja, że przyjęcie nowej Dekady przyniesie pozytywne zmiany w zakresie realizacji EZR w polskich szkołach.
\end{abstract}

Słowa kluczowe: edukacja, rozwój zrównoważony, edukacja na rzecz zrównoważonego rozwoju, Dekada EZR

\begin{abstract}
The paper is a reflection on the state of education for sustainable development (ESD) in Poland, before the announcement of the Decade for Sustainable Development 2020-2030. Its goal was to assess the implementation of ESD in our country, and to develop recommendations for its effectiveness. An analysis of the current core curriculum for primary schools, secondary schools, and technical secondary schools, showed the benefits of providing ESD. Reference was made to research carried out by experts from Stanford University and the "Water Explorer" project. The findings show that although the concept of sustainable development has been taken into account in the core curriculum, the content of environmental education is still being implemented in practice. It turns out that, in view of all the benefits and expectations, ESD is not the "heart and driving force" of the entire education system in Poland. The need for programmes enabling the acquisition of skills and competences for environmental protection, as well as actions motivating students to responsibly react to changes that occur in the environment, still prevail. ESD should be integrated into policies and strategies, developed in the curricula, and widely implemented in schools. It is also necessary to prepare, even train
\end{abstract}


teachers to conduct ESD, point to effective methods, and equip them with appropriate implementation tools. It remains to be seen if the adoption of the "new Decade" will bring positive changes in the field of ESD implementation in Polish schools.

Keywords: education, ecology, sustainable development, education for sustainable development, ESD Decade

\section{Wstęp}

Podczas zorganizowanej 20 marca 2017 r. na Uniwersytecie Kardynała Stefana Wyszyńskiego w Warszawie konferencji poświęconej teorii i praktyce zrównoważonego rozwoju z okazji 30. rocznicy ogłoszenia Raportu Brundtland został podpisany Apel Warszawski o zrównoważony rozwój świata. Uczestnicy konferencji reprezentujący środowiska intelektualistów, przedsiębiorców, organizacji pozarządowych, administracji rządowej i samorządowej, mediów oraz uczniów i studentów apelowali o podjęcie radykalnych działań na rzecz przezwyciężania megatrendów prowadzących do pogłębiającego się kryzysu ekologicznego i głębokiego stanu niezrównoważenia planety. $\mathrm{Na}$ początku XXI w., ponad 30 lat po opublikowaniu raportu Nasza wspólna przyszłość (Our Common Future) i ponad 40 lat od publikacji raportu U Thanta Problemy ludzkiego środowiska (The problems of human environment) stan Ziemi - miejsca życia obecnych i przyszłych pokoleń - wzbudza poważne obawy. Z niepokojem zapoznajemy się $\mathrm{z}$ doniesieniami naukowców na temat zmian klimatycznych i ich skutków, utraty różnorodności biologicznej, zanikania naturalnych, dzikich terenów, pogłębiających się różnic gospodarczych między regionami i krajami oraz wzrostem ubóstwa. Coraz bardziej przerażają następstwa tych niekorzystnych trendów, a w szczególności migracja ludzi, szukających lepszego miejsca do życia, i zagrożenie chorobami. Wszystko to powoduje, że osiągnięcie, przyjętych na 70. sesji Zgromadzenia Ogólnego ONZ we wrześniu 2015 r. w Nowym Jorku, 17 Celów Zrównoważonego Rozwoju z ich szczegółowymi zadaniami wydaje się być niezbędne dla zapewnienia warunków do życia przyszłym, a nawet obecnym pokoleniom.

Realizacja Celów Zrównoważonego Rozwoju wymaga głębokiej transformacji sposobu myślenia i działania. Konieczne jest natychmiastowe podejmowanie radykalnych i kompleksowych działań, które zmienią niekorzystne trendy związane z obecnym niezrównoważonym modelem rozwoju cywilizacyjnego. Muszą one bazować na wiedzy, świadomości i systemie wartości, które można osiągnąć tylko dzięki skutecznej edukacji. Dlatego powszechnie uznaje się, że kluczowym warunkiem wejścia na drogę zrównoważonego rozwoju jest właściwa edukacja.

\section{Wskazania do realizacji edukacji służącej zrównoważonemu rozwojowi}

Od samego początku powstania koncepcji zrównoważonego rozwoju wskazuje się na konieczność podejmowania właściwej edukacji. Wprowadzanie zasad zrównoważonego rozwoju wymaga radykalnych i kompleksowych działań, które zmienią niekorzystne trendy związane $\mathrm{z}$ obecnym niezrównoważonym modelem rozwoju cywilizacyjnego. Odpowiedzialne korzystanie z zasobów naturalnych, zmiana procesów produkcji i stylu konsumpcji, a także poszanowanie sprawiedliwości społecznej i to zarówno obecnie, jak i wobec przyszłych pokoleń wymagają podejmowania niezwłocznych działań opartych na wiedzy, świadomości i systemie wartości, które można osiągnąć tylko dzięki skutecznej edukacji. Dlatego powszechnie uznaje się, że kluczowym warunkiem wejścia na drogę zrównoważonego rozwoju jest właściwa edukacja. 
Aktualnymi drogowskazami wyznaczającymi kierunek zrównoważonego rozwoju jest 17 Celów Zrównoważonego Rozwoju (ONZ 2015, 16), do których osiągnięcia społeczność międzynarodowa powinna dążyć w ciągu najbliższych kilkunastu lat - do 2030 r. Prowadzenie skutecznej edukacji jest wpisane w realizację każdego z Celów Zrównoważonego Rozwoju przyjętych podczas 70. Sesji Zgromadzenia Ogólnego Narodów Zjednoczonych we wrześniu 2015 r. Natomiast ustanowienie Celu 4. - „Zapewnienie edukacji włączającej na wysokim poziomie oraz umożliwienie wszystkim ludziom edukacji przez całe życie" - szczególnie mocno podkreśla zasadnicze znaczenie edukacji dla osiągnięcia wszystkich Celów ZR i poczynienia znaczącego postępu na drodze ich realizacji.

Międzynarodowe uznanie dla edukacji na rzecz zrównoważonego rozwoju (EZR), jako koniecznego warunku dla jego osiągnięcia, stale rośnie. EZR została uznana za taki kluczowy warunek podczas trzech przełomowych globalnych szczytów zrównoważonego rozwoju: konferencji ONZ w 1992 r. w sprawie środowiska i rozwoju w Rio de Janeiro w Brazylii; Światowego Szczytu Zrównoważonego Rozwoju w 2002 r. w Johannesburgu w RPA; konferencji ONZ w 2012 r. ponownie w Rio de Janeiro. EZR jest też przedmiotem ważnych umów globalnych, takich jak Porozumienie Paryskie w sprawie klimatu (Unesco.pl 2020).

Wyspecjalizowana organizacja ONZ ds. edukacji, nauki i kultury UNESCO wspiera rozwój i wdrażanie edukacji na rzecz zrównoważonego rozwoju. Ustanawiając Dekadę EZR (2005-2014) i powierzając koordynację działań UNESCO, Organizacja Narodów Zjednoczonych uznała EZR za kluczowe wyzwanie XXI w. i istotne narzędzie mogące skutecznie przyczynić się do poprawy jakości życia wszystkich ludzi na świecie. Przyjęcie Dekady było jednoznaczne z zobowiązaniem uwzględniania $\mathrm{w}$ treściach i formach edukacji nowego paradygmatu rozwoju. W rozumieniu dokumentu człowiek ma stać się zasadniczym czynnikiem przemian, dlatego niezbędna jest poprawa jakości kształcenia i włączanie w szeroko pojętą edukację dążeń upowszechniających zrównoważony rozwój w wymiarze społecznym, gospodarczym i ekologicznym (Borys 2010, 60). Realizacja Dekady, koordynowanej przez UNESCO, miała zatem wzmocnić rolę EZR i służyć osiągnięciu postępu w tak ważnych i palących kwestiach, jak: wspieranie pokoju na świecie, walka z globalnym ociepleniem, zmniejszenie przepaści rozwojowej między bogatymi a biednymi krajami oraz walka z biedą, przeciwdziałanie marginalizacji kobiet i dziewcząt (Kalinowska 2007, 45).

Ogłoszenie przez ONZ Dekady EZR zaowocowało w 2005 r. przyjęciem Strategii Edukacji dla Zrównoważonego Rozwoju Europejskiej Komisji Gospodarczej ONZ określającej zasady jej realizacji w krajach europejskich:. Nadrzędnym celem Strategii EZR, zgodnie z wytycznymi UNESCO, jest włączanie tematyki zrównoważonego rozwoju do programów nauczania na wszystkich poziomach kształcenia edukacji formalnej oraz do edukacji nieformalnej i pozaformalnej (mimowolnej).

Podsumowanie wyników Dekady odbyło się w dniach 10-12 listopada 2014 r. w Aichi- Nagoya (Japonia) podczas Światowej Konferencji na temat Edukacji dla Zrównoważonego Rozwoju. To ważne spotkanie zgromadziło ponad 1000 uczestników z kilkudziesięciu krajów, wśród których znalazło się 76 przedstawicieli ministerstw z krajów członkowskich UNESCO, reprezentanci organizacji pozarządowych, akademicy, przedstawiciele biznesu oraz młodzieży ze 150 krajów (Unesco.pl 2020).

Zakończenie Dekady EZR nie było zakończeniem wysiłków UNESCO na rzecz edukacji. Podczas konferencji w Nagoi przedstawiciel japońskiego rządu minister Edukacji, Kultury, Sportu, Nauki i Technologii, Hideki Niwa podkreślił, że: „Edukacja dla Zrównoważonego Rozwoju nie kończy się wraz z ostatnim rokiem Dekady. Przeciwnie, powinniśmy teraz zwiększyć zaangażowanie na rzecz EZR, wykorzystując doświadczenie 
zdobyte podczas ostatnich dziesięciu lat" (Unesco.pl 2020).

Kontynuacją działań podjętych na całym świecie było ogłoszenie przez UNESCO, na konferencji w Nagoi, Programu dziatań globalnych edukacji dla zrównoważonego rozwoju (Global Action Programme on Education for Sustainable Development - GAP). Uczestnicy konferencji wyznaczyli Mape drogowa dla edukacji dla zrównoważonego rozwoju, stużaca wdrożeniu Globalnego Programu Działań (Roadmap for implementing the Global Action Programme on Education for Sustainable Development). W dokumencie podkreślono, że porozumienia polityczne, zachęty finansowe i nowoczesne technologie nie są wystarczające do osiągnięcia zrównoważonego rozwoju. Konieczna jest radykalna zmiana w sposobach, w jakich myślimy i w jakich działamy, kształtując nasze relacje z innymi ludźmi i całym ekosystemem Ziemi. Aby trwale zapewnić rozwój, który zaspokoi potrzeby obecnych i przyszłych pokoleń, potrzebne jest wyposażenie wszystkich osób i całych społeczeństw w odpowiednią wiedzę i umiejętności oraz ukształtowanie właściwego systemu wartości.

W 2020 r. rozpocznie się nowy, ważny okres podejmowania konkretnych działań służących zintensyfikowaniu wdrażania edukacji wspierającej zrównoważony rozwój. W czerwcu tego roku, podczas Światowej Konferencji Edukacji na rzecz Zrównoważonego Rozwoju UNESCO w Berlinie, miałaby ogłoszona nowa Dekada Edukacji na Rzecz Zrównoważonego Rozwoju ukierunkowana na osiągnięcie celów zrównoważonego rozwoju do 2030 r. Z uwagi na pandemię COVID -19 konferencja odbędzie się 17-19 maja 2021 r. w Berlinie.

\section{Realizacja edukacji na rzecz zrównoważonego rozwoju w Polsce}

Wydaje się, że współcześnie także w Polsce coraz bardziej utrwala się przekonanie, że edukacja jest kluczowym narzędziem implementacji założeń zrównoważonego rozwoju. Jej celem jest nie tylko przekaz wiedzy, lecz także kształtowanie w człowieku umiejętności zaspokajania własnych aspiracji w sposób umożliwiający realizację tych samych potrzeb przyszłym pokoleniom. W literaturze przedmiotu można odnaleźć wiele definicji EZR odzwierciedlających co najmniej dwa sposoby jej prowadzenia. W pierwszym podejściu zwraca się uwagę na kwestię treści i informacji, dostarczania faktów w celu wpływania na zmianę sposobów myślenia i zachowania odbiorcy. Drugie znaczenie EZR odnosi się do prowadzenia dialogu na temat problemów spornych, niejednoznacznych, w efekcie którego uczestnicy nabywają umiejętność krytycznego myślenia i odpowiedzialnego reagowania na zagrożenia i sytuacje kryzysowe w szerokorozumianym środowisku (Vare and Scott 2007, 192).

W polskim systemie kształcenia formalnego dominują programy nauczania oparte na przekazie wiedzy. Choć wciąż bardziej wpisują się w zakres edukacji ekologicznej (EE), niż EZR, to warto podkreślić, że w podstawie programowej z 2017 i $2018 \mathrm{r}$. w treściach nauczania uwzględniono koncepcję zrównoważonego rozwoju i niektóre jej założenia.

W podstawie programowej edukacji wczesnoszkolnej zwrócono uwagę, że organizacja zajęć ma wspierać m.in.: rozwijanie u dzieci nawyków i zachowań adekwatnych do poznawanych wartości, takich jak: bezpieczeństwo własne i grupy, odpowiedzialność i poczucie obowiązku itp.; poznawanie wartości i wzajemnych powiązań składników środowiska przyrodniczego, a także wartości i norm, których źródłem jest zdrowy ekosystem z uwzględnieniem zachowań wynikających z tych wartości; odkrywanie przez ucznia siebie jako integralnego podmiotu środowiska przyrodniczego; poznawanie kultur innych narodów, różnorodnych zjawisk przyrodniczych wraz z możliwością percepcji i rozumienia tych zagadnień na danym etapie rozwoju ucznia (Podstawaprogramowa.pl 2020). W wymaganiach szczegółowych do treści nauczania, w ramach realizacji edukacji przyrodniczej, społecznej oraz etyki pojawiają się ogólne zakładane 
rezultaty, które można by uznać za część EZR. Dotyczą one budowania świadomości posiadania praw i obowiązków i ich respektowania, ponoszenia odpowiedzialności za swoje wybory, a także istnienia podstawowych zagrożeń ze środowiska naturalnego, kwestii ochrony przyrody, segregacji odpadów i stosowania pojęcia „organizacja ekologiczna”.

Natomiast w podstawie programowej kształcenia ogólnego dla szkoły podstawowej pojawia się zapis: „Szkoła dba o wychowanie dzieci i młodzieży w duchu akceptacji i szacunku dla drugiego człowieka, kształtuje postawę szacunku dla środowiska przyrodniczego, w tym upowszechnia wiedzę o zasadach zrównoważonego rozwoju, motywuje do działań na rzecz ochrony środowiska oraz rozwija zainteresowanie ekologią" (Podstawaprogramowa.pl 2020). Propagowanie wiedzy z zakresu zrównoważonego rozwoju ma odbywać się w ramach treści niektórych przedmiotów. Kształcenie w uczniach właściwych zachowań wobec środowiska przyrodniczego, poznawanie sposobów jego ochrony powinno dokonywać się poprzez nauczanie biologii. W treściach programowych wpisanych do działu „Ekologia i ochrona środowiska” pojawia się zapis: „Uczeń przedstawia odnawialne i nieodnawialne zasoby przyrody oraz propozycje racjonalnego gospodarowania tymi zasobami zgodnie z zasadą zrównoważonego rozwoju" (Podstawaprogramowa.pl 2020). Natomiast założeniem części pt. „Zagrożenie różnorodności biologicznej" jest nabycie przez uczniów umiejętności analizowania wpływu człowieka na bioróżnorodność, uzasadniania konieczności jej ochrony oraz wskazania przykładów gospodarczego użytkowania ekosystemów. Wymagania programowe wpisane w oba wskazane powyżej działy zostały zaplanowane do realizacji w klasie ósmej. W wymaganiach ogólnych dla przedmiotu chemia założono natomiast, że uczeń powinien nabyć wiedzę, która pozwoli mu na rozwiązanie praktycznych problemów. Ma on respektować podstawowe zasady ochrony środowiska i potrafić wykazać wpływ właściwości rozmaitych substancji chemicznych na środowisko przyrodnicze. W wymaganiach szczegółowych pojawiają się zagadnienia związane z ubytkiem warstwy ozonowej, zanieczyszczeniem powietrza i kwaśnych opadów. Kwestia ochrony środowiska, w odniesieniu do edukacji zdrowotnej, zaistniała ponadto w treściach programowych „edukacji dla bezpieczeństwa”. Realizacja treści przedmiotu ma się przyczynić do zdobywania przez uczniów umiejętności ustalania możliwości indywidualnego wkładu w tworzenie środowiskowych warunków korzystnych dla zdrowia, w wymiarze osobistym i zbiorowym.

W podstawie programowej dla przedmiotu etyka stworzono jeden z działów, który wprost dotyczy relacji człowieka do przyrody. Realizacja programu ma w efekcie oznaczać, że uczeń będzie postrzegał środowisko naturalne jako wartość, co przełoży się na jego stosunek do zwierząt oraz zaangażowanie na rzecz ochrony przyrody. W dziale tym pojawia się ważna kwestia odpowiedzialności za przyszłe pokolenia. W odniesieniu do niej zakłada się zdobycie przez uczniów umiejętności rekonstruowania argumentacji z odpowiedzialności za przyszłe pokolenia. EZR może być realizowana również w ramach geografii. We wstępie do podstawy programowej tego przedmiotu pojawia się zapis, że geografia powinna przyczyniać się do „zrozumienia sensu i warunków realizacji zasady zrównoważonego rozwoju (...)" (Podstawaprogramowa.pl 2020). W ogólnych celach kształcenia założono przekazanie wiedzy na temat różnorodnych form działalności człowieka w środowisku i potrzeby racjonalnego korzystania z zasobów naturalnych oraz konsolidowanie wiedzy przyrodniczej ze społeczną, ekonomiczną i humanistyczną. W zakresie umiejętności zwrócono uwagę na potrzebę budowania wśród uczniów potrzeby podejmowania nowych inicjatyw oraz racjonalnych działań na rzecz środowiska społeczno-przyrodniczego. 
Podobnie w podstawie programowej przedmiotu biologia dla czteroletniego liceum ogólnokształcącego oraz pięcioletniego technikum zwrócono uwagę, że szkoła ma kształtować postawę szacunku młodzieży dla środowiska naturalnego i mobilizować do działań na rzecz jego ochrony. W zakresie podstawowym, bezpośrednie odniesienie do koncepcji zrównoważonego rozwoju pojawia się w dziale „Różnorodność biologiczna, jej zagrożenia i ochrona”. Zakłada się bowiem, że uczeń będzie umiał przedstawić istotę zrównoważonego rozwoju. Realizacja programu rozszerzonego pozwoli natomiast uczniom zrozumieć znaczenie racjonalnego gospodarowania zasobami naturalnymi, potrzebę ochrony bioróżnorodności i reagowania na zagrożenia dla środowiska jako wskaźnika zrównoważonego rozwoju. Co więcej, wytyczne podstawy programowej z biologii odnoszą się do potrzeby rozwijania postawy szacunku w stosunku do szerokorozumianego środowiska oraz odpowiedzialnego, a więc zgodnego z ideą zrównoważonego rozwoju, korzystania z jego zasobów. W ramach przedmiotu chemia, uczeń nie tylko ma pozyskać wiedzę, lecz także potrafić ją wykorzystać do rozwiązania problemów, umiejętnie zareagować w przypadku zaistnienia zagrożenia dla środowiska. Konkretne treści związane z ochroną środowiska i zrównoważonym rozwojem wpisano w ostatni dział programu, w efekcie którego uczeń powinien proponować sposoby ochrony środowiska przed skażeniem i niszczeniem, zgodnie z zasadami zrównoważonego rozwoju. EZR może być właściwie realizowana na geografii. Tworząc podstawę programową dla tego przedmiotu, za główny jego cel uznano zintegrowane podejście do nauczanych treści dotyczących Polski i świata. Założono, że ważne jest ukazywanie zjawisk i procesów przyrodniczych oraz społeczno-gospodarczych w kontekście wzajemnych odniesień i uwarunkowań, z uwzględnieniem także wzajemnych relacji na styku człowiek - środowisko naturalne. Wskazuje się przy tym za kluczowe zrozumienie przez uczniów zasadności i celu implementacji postulatów zrównoważonego rozwoju. W odniesieniu do współczesnych problemów globalnych, które wpisują się w zakres EZR, nie bez znaczenia jest realizacja podstawy programowej przedmiotu wiedza o społeczeństwie, $\mathrm{w}$ tym treści odnoszących się do praw człowieka, wspólnotowości, sprawiedliwości społecznej, odpowiedzialności itd.

W podstawie programowej kształcenia ogólnego zarówno dla szkoły podstawowej, jak i liceum oraz technikum zwrócono uwagę na walory i znaczenie stosowania metody projektu. Zakłada ona samodzielność i odpowiedzialność uczestników, uczy rozwiązywania problemów oraz umożliwia nabywanie określonych kompetencji. O wyborze treści podstawy programowej, które będą realizowane tą metodą, oraz o czasie trwania projektu decyduje nauczyciel. Metoda ta może więc stanowić jedną z lepszych form EZR i uzupełniać czy poszerzać treści programowe w zakresie zrównoważonego rozwoju.

EZR w wymiarze formalnym wspierana jest kształceniem pozaformalnym, realizowanym przede wszystkim przez projekty opracowywane i wdrażane przez organizacje pozarządowe, samorządy i instytucje lokalne. Swoim zasięgiem dociera nie tylko do dzieci i młodzieży, lecz także - choć wciąż w niezadowalającym stopniu - do osób dorosłych.

Założenia EZR urzeczywistniane są także za pośrednictwem edukacji globalnej, która stosuje podobne, a nieraz te same, metody i narzędzia. Autorzy „Ekspertyzy dotyczącej edukacji dla zrównoważonego rozwoju w Polsce" zwrócili uwagę, że w dalszym ciągu w EZR największy nacisk kładzie się na kwestie środowiskowe, podczas gdy w edukacji globalnej - na społeczne (MNiSW.gov. pl 2012, 64). W Polsce EZR kojarzona jest przede wszystkim z EE. Ogranicza się ona zasadniczo do kwestii związanych z ochroną przyrody, skutków negatywnej działalności człowieka w środowisku, zagrożeń dla zdrowia ludzkiego, np. w wyniku smogu. Brakuje w niej ukierunkowania na rozwijanie w uczestnikach procesu edukacyjnego 
kompetencji do działania na rzecz środowiska społeczno-przyrodniczego w sytuacjach konfliktowych, w których ujawniają się sprzeczności pomiędzy interesami gospodarczymi, społecznymi i dobrem przyrody. Nabywanie tego rodzaju kompetencji jest niezwykle ważne, a niestety w edukacji wciąż brakuje kompleksowego podejścia do zagadnień zrównoważonego rozwoju.

\section{Korzyści wynikające z prowadzenia edukacji służącej zrównoważonemu rozwojowi dla ucznia i rozwoju jego kompetencji}

Międzynarodowa, pod przywództwem UNESCO, mobilizacja do powszechnego wdrażania edukacji na rzecz zrównoważonego rozwoju zaowocowała ogromną ilością podejmowanych działań, projektów, opracowań, badań naukowych oraz oficjalnych wytycznych, takich jak przyjęcie w krajach europejskich Strategii Edukacji dla Zrównoważonego Rozwoju Europejskiej Komisji Gospodarczej ONZ (Europejska Komisja Gospodarcza ONZ 2008).

Na pytanie: jak zalecenia tych ważnych zobowiązań do realizacji EZR w szkole zostały wprowadzone w praktyce, częściowo odpowiada raport podsumowujący osiągnięcia Dekady EZR Shaping the Future We Want. Według raportu w obszarze edukacji formalnej szkoły podstawowe i ponadpodstawowe (nasze gimnazja) są placówkami najbardziej zaawansowanymi w prowadzeniu EZR. Prawie $40 \%$ państw członkowskich za największy sukces Dekady uznało wprowadzenie EZR do programów podstawy programowej. W trakcie Dekady odbyło się łącznie 22 tysiące konsultacji, warsztatów, szkoleń oraz innych form wzmacnia EZR w szkołach podstawowych i ponadpodstawowych oraz wydano łącznie 18 tysięcy materiałów wspierających realizację treści EZR w ramach podstawy programowej (UNESCO 2014).

W tym miejscu warto sobie zadać pytanie: jakie korzyści z prowadzenia edukacji służącej zrównoważonemu rozwojowi odnoszą sami uczniowie. Eksperci z Uniwersytetu Stanforda podjęli badania polegające na systematycznym przeglądzie literatury akademickiej. W efekcie zidentyfikowali 119 recenzowanych badań opublikowanych w latach 1994-2013, które mierzyły wpływ EE na uczniów w wieku od przedszkola do lat dwunastu. Przegląd wykazał wyraźne dowody na to, że wspierająca zrównoważony rozwój EE jest potężnym sposobem efektywnego nauczania uczniów, przynoszącym wielorakie korzyści: od poprawy wyników w nauce i umiejętności krytycznego myślenia, do rozwoju osobistego i umiejętności budowania zaufania, autonomii i przywództwa. Ponadto wiele badań wykazało, że EE zwiększyła zaangażowanie obywatelskie i pozytywne zachowania prośrodowiskowe. W ponad 100 pracach badacze dowiedli, że ten rodzaj edukacji zapewnia transformacyjne możliwości uczenia się (Ardoin, Bowers, Roth, and Holthuis 2018, 14).

Badania dotyczące zmiany postaw i wartości uczniów prowadzi dr Anna Doerling z Uniwersytetu Westminster w odniesieniu do uczestników międzynarodowego programu edukacji ekologicznej Badacz Wody (Water Explorer), w którym biorą udział również szkoły z Polski. Jest to międzynarodowy program edukacyjny dla uczniów w wieku 8-14 lat (badaczwody.pl 2020). Program, którego celem jest nauczenie uczniów szacunku do wody poprzez wspólne poszukiwanie rozwiązań i stawianie czoła globalnym wyzwaniom związanym z ochroną i racjonalnym korzystaniem z tego cennego zasobu, jakim jest woda. Uczestnicy programu podejmują wyzwania badawcze, komunikacyjne i kampanijne w czterech obszarach misji: „Cenna woda”, „Czysta woda”, „Tajemnicza woda” i „Woda na świecie”. Kulminacją doświadczeń jest „Festiwal wody” dla społeczności. Za wprowadzanie programu Badacz Wody w polskich szkołach odpowiada Fundacja Gospodarki i Administracji Publicznej (Fundacja GAP), ucząca ekologicznych zachowań i promująca zrównoważony rozwój. Inicjatorom oraz krajowym koordynatorom programu zależy, aby oprócz zmiany zachowania i oszczędzania wody uczniowie stali się odpowiedzialnymi 
"ambasadorami wody", aby wyznawali wartości altruistyczne i przyjazne dla środowiska, które staną się zasadami przewodnimi w ich i dzięki którym będą przykładem dla przyjaciół, rodziny i społeczności.

Diagram przedstawiony na rys. 1 pokazuje wagę, jaką jeden z polskich, szkolnych zespołów uczestniczących w projekcie, przywiązuje do 10 Wartości według Schwartza przed (pole niebieskie) i po (pole pomarańczowe) udziale w projekcie Badacz Wody.

Korzystając z uznanej w świecie teorii Wartości Schwartza badaczka mierzyła zmianę wagi poszczególnych wartości wybieranych przez dzieci i młodzież uczestniczących w projekcie Badacz Wody. Przyjmuje się powszechnie, że im większą wagę młodzież przykłada do wartości, o których wiadomo, że promują postawy i nawyki zrównoważonego stylu życia, tym bardziej przekłada się to na jej faktyczne zachowania w sposób zrównoważony w życiu codziennym. Badania oparte na modelu wartości Schwartza, podjęte przez A. Doerling, dotyczące tego programu wykazały, że uczestniczenie $\mathrm{w}$ nim zmienia system wartości uczniów i może prowadzić do przeobrażeń w ich zachowaniu.

\section{Wnioski}

W podstawie programowej z 2017 i 2018 r., w treściach nauczania uwzględniono koncepcję zrównoważonego rozwoju i niektóre jej założenia. Tym samym nauczyciel ma możliwość realizowania EZR. Praktyka pokazuje jednak, że w szkołach w dalszym ciągu omawiane są zagadnienia bliższe EE. Co więcej, w systemie kształcenia formalnego przeważają programy oparte na przekazie wiedzy. Ich walorem jest dostarczanie faktów i informacji, które mogą wpływać na zmianę sposobów myślenia oraz zachowań uczniów. Podejście to powinno być jednak uzupełniane programem umożliwiającym nabywanie umiejętności i kompetencji, które będą determinować do odpowiedzialnego reagowania na zmiany, jakie dokonują się w środowisku społeczno-przyrodniczym.
Warto podkreślić, że w Polsce istnieje wiele organizacji oferujących bardzo ciekawe programy edukacji służącej zrównoważonemu rozwojowi i angażujących rzesze uczniów i nauczycieli biorących udział w tych programach. Nadal jednak wydaje się, że jest to edukacja „dla entuzjastów", która prowadzona jest jedynie w tych szkołach, które kierowane są przez dyrektorów świadomych i otwartych na zagadnienia zrównoważonego rozwoju. Nie jest to jednak edukacja będąca misją szkoły jako placówki zrównoważonego rozwoju, która oddziałuje na uczniów przez całościowe funkcjonowanie zgodne z zasadami zrównoważonego rozwoju i która angażuje uczniów, skłania do refleksyjnego myślenia i podejmowania działań służących zrównoważonemu rozwojowi zarówno w szkole, jak i w ich życiu prywatnym.

Naukowcy i eksperci przygotowujący dla UNESCO dokumenty programowe, których celem jest opracowanie wskazówek dla każdego szczebla profesjonalistów odpowiedzialnych za wdrażanie EZR, podkreślają, że osiągnięcie poziomu i właściwej jakości edukacji, która zgodnie z zamierzeniami realizowałaby zadania wyznaczone w 17 . Celach Zrównoważonego Rozwoju, musi spełnić następujące rekomendacje:

\section{Włączanie EZR do polityk, strategii} i programów

Polityka jest kluczowym czynnikiem pozwalającym na włączanie EZR do wszystkich formalnych i nieformalnych systemów uczenia. Potrzebna jest odpowiednia i spójna polityka umożliwiająca zmianę edukacji na taką, która będzie odpowiadała na wyzwania zrównoważonego rozwoju zawarte w Agendzie 2030 i 17. Celach Zrównoważonego Rozwoju.

2. Włączanie EZR do programów nauczania i treści podręczników

EZR musi być zintegrowana ze wszystkimi programami edukacji formalnej od edukacji wczesnoszkolnej poprzez edukację w szkołach podstawowych i ponadpodstawowych oraz edukację zawodową i szkolnictwo wyższe. EZR powinna stanowić rdzeń nauczania, 


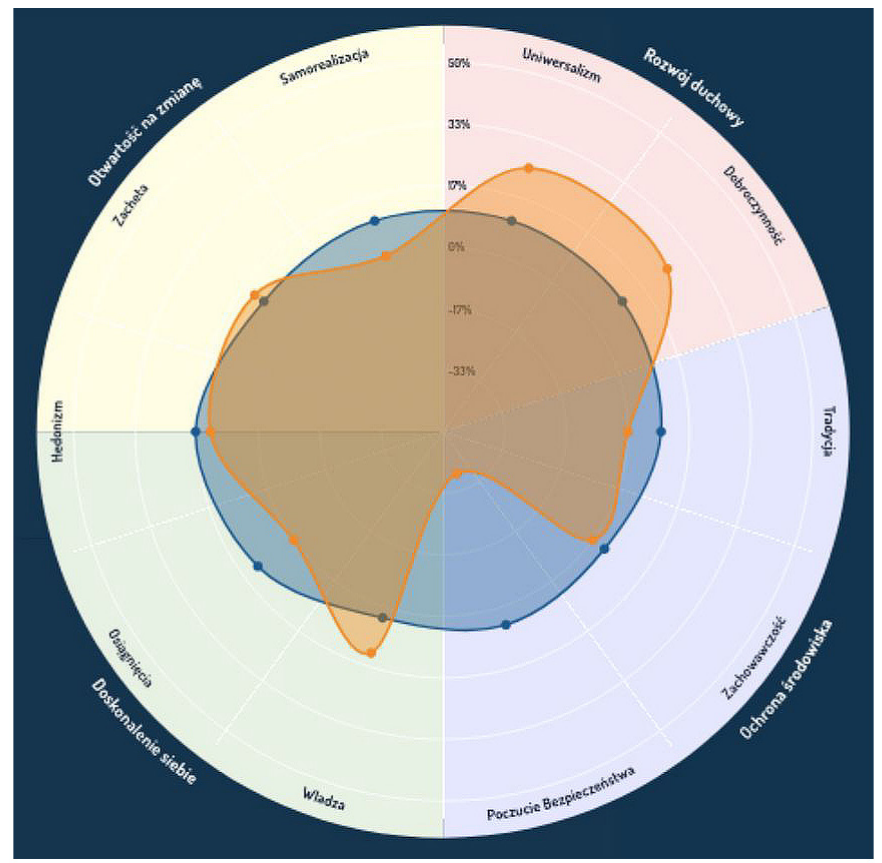

Rys. 1. Schemat zmian wartości u uczniów biorących udział programie edukacyjnym Badacz Wody w SP1 w Koluszkach (2016 r.) wg badań dr A. Doerling z Uniwersytetu Westminster

a nie być traktowana jako dodatek do istniejącego programu nauczania.

3. Przygotowanie nauczycieli do prowadzenia EZR

Nauczyciele i edukatorzy odgrywają kluczową rolę w podejmowaniu i skutecznej realizacji EZR. Ich wiedza i kompetencje są niezbędne do restrukturyzacji procesów edukacyjnych i instytucji edukacyjnych w kierunku zrównoważonego rozwoju. Dlatego przygotowanie nauczycieli, zarówno na etapie edukacji formalnej, podczas której są przysposabiani do zawodu, jak i poprzez możliwość uczestniczenia w szkoleniach doskonalących, ma zasadnicze znaczenie.

4. Realizacja EZR w szkole i wdrożenie odpowiednich metod nauczania

EZR to nie tylko nauczanie o zrównoważonym rozwoju oraz dodawanie nowych treści do kursów i szkoleń. Szkoły i uniwersytety powinny postrzegać siebie jako miejsca zdobywania bezpośrednich doświadczeń i umiejętności w zakresie zrównoważonego rozwoju. Skuteczność EZR należy wiązać z przemianą szkoły w instytucję funkcjonującą według zasad zrównoważonego rozwoju. Aby jednak EZR była efektywna, nie wystarczy zmiana placówki edukacyjnej w placówkę zrównoważonego rozwoju, motorem bowiem owocnej EZR są odpowiednie metody nauczania. Rekomendowane podejście pedagogiczne opiera się na korzystaniu $\mathrm{z}$ aktywizujących metod nauczania skoncentrowanych na uczniu. $\mathrm{Na}$ uczyciel organizuje proces uczenia się, rozpoznając i badając potrzeby i oczekiwania uczniów.

\section{Bibliografia}

Ardoin, Nicole M., Alison W. Bowers, Noelle Wyman Roth, and Nicole Holthuis. 2018. „Environmental education and K-12 student outcomes: A review and analysis of research." The Journal of Environmental Education 49(1): 1-17. https://doi.org/10.1 080/00958964.2017.1366155.

Badaczwody.pl. 2020. Program Badacz Wody. Dostęp 20.02.2020. https://www.badaczwody.pl/home.

Borys, Tadeusz. 2010. „Dekada edukacji dla zrównoważonego rozwoju - polskie wyzwania." Problemy Ekorozwoju 5(1): 59-70. 
Döring, Anna K., Ella Daniel, and Ariel Knafo-Noam. 2016. „Value development from middle childhood to early adulthood: New insights from longitudinal and genetically informed research." Social Development 25(3): 471-481. https://doi.org/10.1111/ sode.12177.

Europejska Komisja Gospodarcza ONZ. 2008. Strategia Edukacji dla Zrównoważonego Rozwoju. Warszawa: Ministerstwo Środowiska. Dostęp 30.03.2020. http://nauczyciele.mos.gov.pl/index. php?app $=$ docs\&action $=$ get\&iid $=1274$.

Kalinowska, Anna. 2007. „Dekada Edukacji dla Zrównoważonego Rozwoju - zmniejszanie barier." W Wybrane zagadnienia z ekologii i ochrony środowiska. Teoria i praktyka zrównoważonego rozwoju. Wybór wyktadów z lat 2004-2007, red. Anna Kalinowska i Witold Lenart, 45-50. Warszawa: Uniwersyteckie Centrum Badań nad Środowiskiem Przyrodniczym.

MNiSW.gov.pl. 2012. Ekspertyza dotyczaca edukacji dla zrównoważonego rozwoju w Polsce - raport końcowy. Dostęp: 30.03.2020. https://archiwum. mos.gov.pl/fileadmin/user_upload/Ekspertyza_ dotyczaca_edukacji_dla_zrownowazonego_rozwoju_w_Polsce.pdf.
ONZ. 2015. Agenda na rzecz zrównoważonego rozwoju 2030, ONZ 2015 (A/RES/70/1).

Podstawaprogramowa.pl. 2020. Podstawa programowa ksztatcenia ogólnego dla szkoty podstawowej. Dostęp 7.03.2020. https://podstawaprogramowa.pl.

UNESCO. 2012. Education for sustainable development: Sourcebook. Paris: UNESCO. Accessed 30.03.2020. https://sustainabledevelopment.un.org/content/documents/926unesco9.pdf.

UNESCO. 2014. Shaping the Future We Want, UN Decade of Education for Sustainable Development (2005-2014), Final Report. Paris: UNESCO. Dostęp 30.03.2020. https://unesdoc.unesco.org/ ark:/48223/pf0000230171.

Unesco.pl. 2020. Światowa Konferencja Edukacji dla Zrównoważonego Rozwoju. Dostęp 7.03.2020. http://www.unesco.pl/edukacja/dekada-edukacji-nt-zrownowazonego-rozwoju/neste/1/ article/37/swiatowa-konferencja-na-temat-edukacji-dla-zrownowazonego-rozwoju/.

Vare, Paul, and William Scott. 2007. "Learning for a Change: Exploring the Relationship between Education and Sustainable Development." Journal of Education for Sustainable Development 1(2): 191-198. 